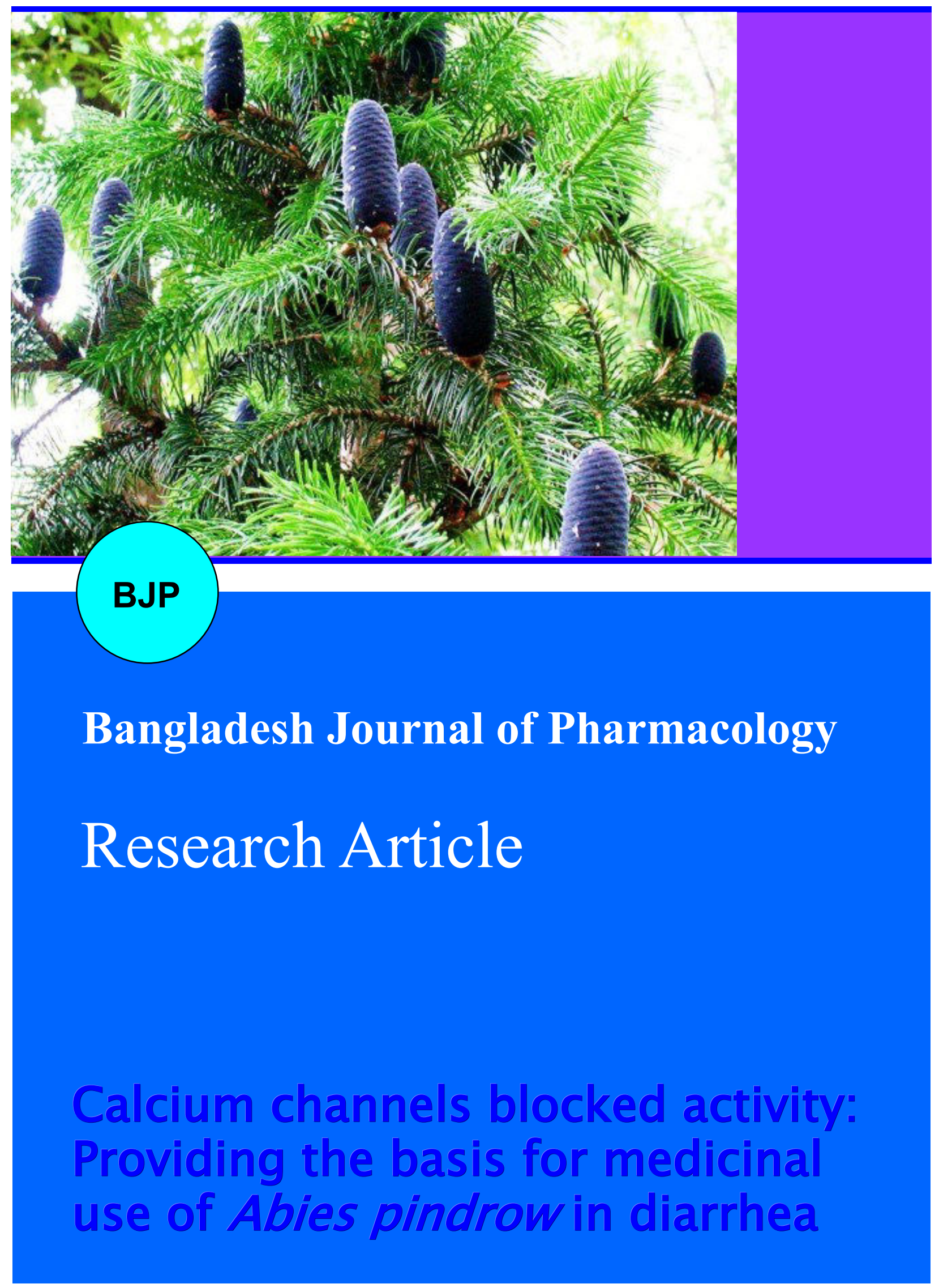




\title{
Calcium channels blocked activity: Providing the basis for medicinal use of Abies pindrow in diarrhea and bronchitis
}

\author{
Sohaib Mushtaq1, Mueen Ahmad Chaudhry' and Hafiz Muhammad Abdul Rahman² \\ ${ }^{1}$ Faculty of Pharmacy, The University of Lahore, Lahore, Pakistan; ${ }^{2}$ Faculty of Pharmacy, \\ University of South Asia, Lahore, Pakistan.
}

\begin{tabular}{|c|c|}
\hline \multicolumn{2}{|l|}{ Article Info } \\
\hline Received: & 15 February 2015 \\
\hline Accepted: & 23 March 2015 \\
\hline Available Online: & 19 May 2015 \\
\hline \multicolumn{2}{|c|}{ DOI: 10.3329/bjp.v10i2.22246 } \\
\hline \multicolumn{2}{|c|}{$\begin{array}{l}\text { Cite this article: } \\
\text { Mushtaq S, Chaudhry MA, Rahman } \\
\text { HMA. Calcium channels blocked } \\
\text { activity: Providing the basis for me- } \\
\text { dicinal use of Abies pindrow in diar- } \\
\text { rhea and bronchitis. Bangladesh J } \\
\text { Pharmacol. 2015; } 10: 430-35 \text {. }\end{array}$} \\
\hline
\end{tabular}

\begin{abstract}
Abies pindrow is widely used in traditional practice for the treatment of diarrhea and bronchitis and the present study was designed to validate its folkloric uses. The crude extract of $A$. pindrow inhibit spontaneously contracting $(1-10 \mathrm{mg} / \mathrm{mL})$ and high $\mathrm{K}^{+}(80 \mathrm{mM})$-induced pre-contracted rabbit jejunum $(3 \mathrm{mg} / \mathrm{mL})$ in concentration dependent manner. A rightward shift in $\mathrm{Ca}^{2+}$ concentration response curves was seen in the presence of crude extract (0.1-0.3), similar to verapamil. In isolated tracheal tissue, A. pindrow inhibited, high $\mathrm{K}^{+}$and carbachol $(1 \mu \mathrm{M})$-induced contractions, at $3 \mathrm{mg} / \mathrm{mL}$ and $10 \mathrm{mg} / \mathrm{mL}$ respectively, similar to that caused by verapamil. These results indicate the presence of calcium channels blocked activity in crude extract of $A$. pindrow, which provide sound basis for medicinal uses of $A$. pindrow in diarrhea and bronchitis.
\end{abstract}

\section{Introduction}

Abies pindrow Royle (Pinaceae), commonly known as "West Himalayan Fir", is found mainly in Himalayas deciduous forests from Afghanistan to Nepal and all over the Western Himalaya (Asolkar et al., 1992). The plant has been used traditionally as expectorant, bronchial sedative, decongestant, anticatarrhal, antiseptic, antispasmodic and carminative (Khare, 2007). It also has bronchodilator, headache relieving and antiperiodic activity (Chopra et al., 1956). The powder of leaves is used as a remedy for fever and juice is employed as a tonic in parturition (Nadkarni, 1996). Apart from its leaves, the bark is also used as a remedy in cough and bronchitis (Radha et al., 2013).

Different studies have evaluated $A$. pindrow for the presence of antioxidant, broncho-protective, anti-ulcerant, analgesic, anti-inflammatory, hypotensive (Majeed et al., 2013) and anxiolytic activities (Kumar et al., 2000).

Phytochemical studies revealed that the plant contain phenols, flavonoids, terpenoids, steroids and glycoside.
Stem of $A$. pindrow contains phytochemicals like hydroxylflavanone, gluco-pyranoside and chalcone-glycoside. Whereas, leaf contains bioflavonoids, flavornoids, pindrolactone, pentacyclic triterpenoids, phenolic compounds, pinitol and carbohydrates. It also contain saturated and unsaturated fatty acids with isopalmitic acid as the most prominent saturated fatty acid and oleic acid as the principal unsaturated acid and someother important hydrocarbons includes 1-octadecene and 1-docosene (Majeed et al., 2013).

Despite of medicinal importance of $A$. pindrow in traditional practice, no scientific data are available regarding to its effectiveness in gut motility and airways disorders. The present study on the crude extract of $A$. pindrow was conducted to validate these traditional uses and to explore mechanistic basis for these medicinal uses.

\section{Materials and Methods}

Plant material 
A. pindrow leaves were purchased from local market in Lahore, Pakistan and were subsequently identified by an expert taxonomist, Dr. Amin Ullah Shah, Department of Botany, University of Sargodha, Sargodha, Pakistan (voucher\# 6031) and specimen was submitted to herbarium. Leaves were getting rid of adulterants and were subjected to an electrical blender in order to make a coarse powder.

\section{Preparation of crude extract}

Extract was prepared by clod maceration as previously followed by (Qureshi et al., 2015). $400 \mathrm{~g}$ of powdered leaves were soaked in $70 \%$ aqueous-methanolic solution and kept for 7 days at room temperature with occasional shaking. Filtration was done by using the muslin cloth and subsequently by Whatman No. 1 filter paper. Thereafter, the filtrate was evaporated using a rotary evaporator, stabilized at a reduced pressure (-760 $\mathrm{mmHg})$ and temperature $\left(40-45^{\circ} \mathrm{C}\right)$ until a thick mass was formed. The concentrate was then transferred to glass bottle stored in refrigerator $\left(-20^{\circ} \mathrm{C}\right)$ until next use.

\section{Preliminary phytochemical analysis}

Qualitative phytochemical analysis of extract was done for the presence of alkaloids, anthraquinones, coumarins, saponins, and tannins as described previously (urRahaman et al., 2013).

\section{Chemicals}

Research grade chemicals were used for experimental work. Acetylcholine chloride, carbamoyl-choline chloride and verapamil hydrochloride (Sigma-Aldrich Co.St. Louis, MO, USA), calcium chloride, glucose, methanol, magnesium chloride, magnesium sulphate, potassium chloride, potassium dihydrogen phosphate, sodium bicarbonate, sodium dihydrogen phosphate and sodium chloride (Mereck Darmstadt, Germany) were purchased from authentic sources.

\section{Preparation of solutions}

Stock solutions $\left(10^{-2} \mathrm{M}\right)$ of standard drugs (acetylcholine, carbachol and verapamil) were prepared in distilled water and stored at $-20^{\circ} \mathrm{C}$. All the physiological solutions (Tyrode's, Kreb's, Tyrode's rich and Tyrode's normal solution), dilutions of standard drugs from their respective stock solutions and of extract were prepared freshly on the same day in the distilled water.

\section{Animals}

Locally breed rabbits (weighing 1-1.5 Kg) of either sex were used for study, acclimatized at room temperature $\left(23-25^{\circ} \mathrm{C}\right)$ for a week in the animal house of The University of Lahore, Lahore before experimental work, provided with standard diet and tap water. Animals decapitated by blow behind the neck, were subjected to starvation for 24 hours prior to dissection but were given free access to water. Experimentation was carried out in accordance to the guidelines by Institute of Laboratory Animal Resources, Commission on Life Sciences, National Research Council (ILAR, 1996), as approved by the ethical committee of The University of Lahore, Lahore, Pakistan.

\section{In vitro experiments}

All the in vitro experiments were performed as per protocols previously described by (Chaudhary et al., 2012).

\section{Rabbit jejunum}

Rabbit jejunum was dissected out after decapitation and immersed in Tyrode's solution. Approximately a segment of 2-3 cm clean from mesentery was cut and mounted in tissue organ bath $(20 \mathrm{~mL})$, prefilled with physiological solution (Tyrode's solution), sustained at $37^{\circ} \mathrm{C}$ and continuously aerated with carbogen $\left(95 \% \mathrm{O}_{2}\right.$ : $5 \% \mathrm{CO}_{2}$ ). A preload of $1 \mathrm{~g}$ was provided to the tissue and equilibrated for approximately $30 \mathrm{~min}$ before given any treatment. Then, tissue was stabilized with sub maximal concentration $(0.3 \mu \mathrm{M})$ of acetylcholine by $3-5$ times and subsequent washing with Tyrode's solution until effects of acetylcholine were superimposed. Once the tissue response was stabilized the crude extract was run in cumulative dose fashion to screen the possible gut modulatory effect. Tissue responses were recorded on Lab Chart 7 by using isotonic transducers and Power Lab data acquisition system (26T).

\section{Demonstration of calcium antagonist activity}

In order to unveil, whether the relaxant effect of the crude extract was through calcium channel blocking activity, high $\mathrm{K}^{+}(80 \mathrm{mM})$ was used. It is well known to depolarize the smooth muscles and generate myocontractions by opening of the voltage gated calcium channels (Nadal et al., 2002). An agent inhibiting the contractions produced by the High $\mathrm{K}^{+}$is thought to be a calcium channel blocker (Godfraind et al., 1986). To confirm the $\mathrm{Ca}^{+2}$ channel blocking activity of the crude extract, calcium concentration response curves were constructed. Tissue was stabilized in Tyrode's solution, which was subsequently substituted with calcium free Tyrode's solution, having EDTA $(0.1 \mathrm{mM})$. Tissue was allowed to suspend for approximately half an hour to remove intracellular $\mathrm{Ca}^{+2}$ from the tissues (Farre et al., 1991). The solution was replaced with potassium rich and calcium free Tyrode's solution. After constructing two super-imposable calcium response curves on base line, tissue was subjected to incubate with crude extract for $50 \mathrm{~min}$ and curves were constructed also in the presence of different concentrations of crude extract, similarly with the case of verapamil, as it was used as positive control.

\section{Rabbit trachea}

Rabbit trachea was dissected out after decapitation and immersed in physiological solution (Kreb's solution). 
Approximately a segment of trachea containing 2-3 cartilage rings, free from connective tissue was cut. A tracheal strip was made by opening these rings with longitudinal incision on C-shaped cartilage, opposite to the smooth muscle layer. This tracheal strip having central part of smooth muscles sandwich between the cartilage portions on the edges, was mounted in tissue organ bath $(20 \mathrm{~mL})$, prefilled with Kreb's solution, sustained at $37^{\circ} \mathrm{C}$ and continuously aerated with carbogen. A preload of $1 \mathrm{~g}$ was given to the mounted tracheal preparation and allowed untreated for $60 \mathrm{~min}$ to equilibrate. The tissue response was stabilized with carbachol $(1 \mu \mathrm{M})$ by $2-3$ times with subsequent washing by Kreb's solution. Once the tissue response was stabilized, a sustained contraction was induced by carbachol $(1 \mu \mathrm{M})$ or High $\mathrm{K}^{+}(80 \mathrm{mM})$ and challenged with the extract in cumulative dose fashion, to observe the possible broncho-relaxant effect of crude extract. Similarly in the case of verapamil, as it was used as positive control. Tissue responses were recorded on Lab Chart 7 by using isometric transducers and Power Lab data acquisition system (AD Instruments, Sydney, Australia, 26T)

\section{Statistical analysis}

All the data were expressed as mean \pm standard error mean (SEM). Median effective concentrations (EC $\mathrm{E}_{50}$ values) are given with $95 \%$ confidence intervals (CI).

\section{Results}

The tests were performed for the presence of different chemical constituents in the crude extracts of $A$. pindrow leaves and the results are shown in Table I.

When treated spontaneously, a concentration (0.01-10 $\mathrm{mg} / \mathrm{mL}$ ) dependent spasmolytic effect of crude extract was observed in isolated rabbit jejunum (Figure 1A), similar to verapamil $(0.01-3 \mu \mathrm{M})$ with $\mathrm{EC}_{50}$ value of 1.2 $\mathrm{mg} / \mathrm{mL}(95 \% \mathrm{CI}, 0.5-2.8, \mathrm{n}=3)$ and $0.6 \mu \mathrm{M}(0.3-1.3, \mathrm{n}=5)$
Table I

\begin{tabular}{|lc|}
$\begin{array}{l}\text { Results of preliminary phytochemical screening of } \\
\text { crude extracts of } \boldsymbol{A} \text {. }\end{array}$ \\
\hline pindrow
\end{tabular}

(Figure 1B). Crude extract also concentration dependently relaxed high $\mathrm{K}^{+}(80 \mathrm{mM})$ and carbachol $(1 \mu \mathrm{M})$ induced contracted rabbit jejunum, at the dose of $3 \mathrm{mg} /$ $\mathrm{mL}$ and $10 \mathrm{mg} / \mathrm{mL}$ with $\mathrm{EC}_{50}$ value of $0.5 \mathrm{mg} / \mathrm{mL}(0.4-$ $0.6, \mathrm{n}=4)$ and $1.2 \mathrm{mg} / \mathrm{mL}(0.6-2.3, \mathrm{n}=4)$ (Figure $2 \mathrm{~A}$ ), similar to verapamil at 3 and $5 \mu \mathrm{M}$ with $\mathrm{EC}_{50}$ value 0.1 $\mu \mathrm{M}(0.1-0.2, \mathrm{n}=4)$ and $0.4 \mu \mathrm{M}(0.4-0.5, \mathrm{n}=4)$ (Figure 2B), respectively. Crude extract shifted calcium concentration response curves towards right in concentration dependant manner $(0.1-0.3 \mathrm{mg} / \mathrm{mL})$ (Figure $3 \mathrm{~A})$, similar to verapamil $(0.03-0.1 \mu \mathrm{M})$ as shown in Figure 3B.

When tested on isolated rabbit trachea, crude extract caused concentration dependent inhibition of high $\mathrm{K}^{+}$ and carbachol-induced contractions and completely relaxed tracheal tissue at the dose of $3 \mathrm{mg} / \mathrm{mL}$ and 10 $\mathrm{mg} / \mathrm{mL}$ with $\mathrm{EC}_{50}$ value of $0.6 \mathrm{mg} / \mathrm{mL}(0.5-0.8, \mathrm{n}=5)$ and $1.5 \mathrm{mg} / \mathrm{mL}(1.02-2.3, \mathrm{n}=4)$ (Figure $4 \mathrm{~A})$, similar to verapamil at 3 and $5 \mu \mathrm{M}$ with $\mathrm{EC}_{50}$ value of $0.2 \mu \mathrm{M}(0.1$ $0.2, \mathrm{n}=3)$ and $0.7 \mu \mathrm{M}(0.6-0.9, \mathrm{n}=3$ ) (Figure $4 \mathrm{~B})$, respectively.

\section{Discussion}

As per its folkloric repute in GIT and airways disorders (Khare, 2007), the crude extract of A. pindrow was pharmacologically investigated on isolated tissue preparations to authenticate its medicinal uses and
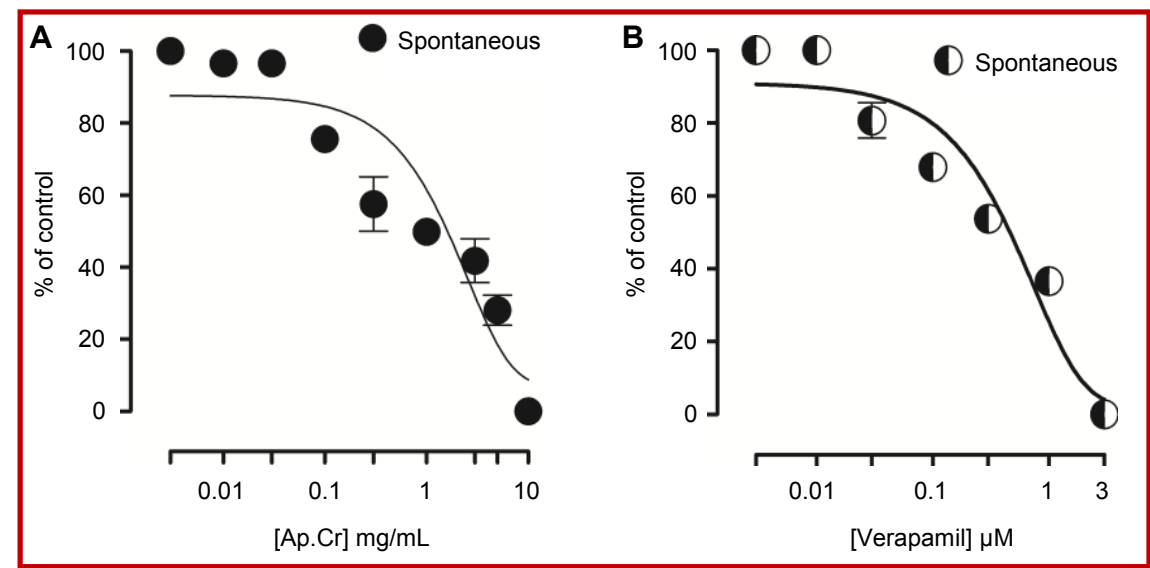

Figure 1: Concentration dependent inhibitory effect of (A) crude extract of A. pindrow (Ap.Cr) and (B) verapamil on spontaneously contracting isolated jejunum. Values are expressed as mean \pm S.E.M; $n=3-5$ 
explore possible underlying mechanism. Because isolated tissue preparations are used conventionally to evaluate the underlying mechanism of action, of crud extracts. This in return allows recording of intrinsic tissue responses without any interruption from hormonal or neural basis (Yasin et al., 2014). A. pindrow is known for its tradition-al uses as anti-diarrheal remedy (Awan, 1960). So, crude extract was tested for its possible spasmolytic effect on spontaneously contracting jejunum and a concentration dependent (0.01-10 $\mathrm{mg} / \mathrm{mL}$ ) spasmolytic effect was observed. The contractions of smooth muscle preparations rely directly upon the increase in intracellular $\mathrm{Ca}^{2+}$. This augmentation in the level of intracellular $\mathrm{Ca}^{2+}$ is due to either inrush of $\mathrm{Ca}^{2+}$ through voltage gated L-Type calcium channels or discharge from sarcoplasmic reticulum (Berridge et al., 2003). However, spontaneous movements of the intestine are modulated through cyclic depolarization and at the peak of depolarization, action potential represents itself as brisk-inrush of the calcium through L-type calcium channels (Brading, 1981).

Since, crude extract showed spasmolytic effect that is similar to verapamil, a calcium channel blocker (Michael and Hoffman, 2011). In our previous studies, involvement of calcium channel blocking activity was observed as underlying cause of spasmolytic effect of crude extract (urRahaman et al., 2013; Chaudhary et al., 2012). To explore possible mechanisms behind spasmolytic effect, high $\mathrm{K}^{+}(80 \mathrm{mM})$ and carbachol $(1$ $\mu \mathrm{M})$-induced contraction on isolated rabbit jejunum were challenged with the extract. The crude extract completely relaxed high $\mathrm{K}^{+}$-induced contractions at $(3$ $\mathrm{mg} / \mathrm{mL}$ ) earlier concentration than carbachol-induced contraction $(10 \mathrm{mg} / \mathrm{mL})$, a typical characteristic of pure calcium channel blocker (Ahmed, 1992), similar to verapamil $(3 \mu \mathrm{M})$. It is well established that $\mathrm{K}^{+}$at higher concentration $(>30 \mathrm{mM})$ is known to induce smooth muscle contraction via opening of L-type calcium channels that results in the inrush of extracellular calcium (Bolton, 1979). Any agent that inhibits high $\mathrm{K}^{+}-$ induced contraction is considered to be the calcium channel blocker (Godfraind et al., 1986).

The presence of calcium channel blocking constituent(s) in crude extract was further strengthened, when a rightward shift was observed in the calcium concentration response curves in the presence of crude extract $(0.1-0.3 \mathrm{mg} / \mathrm{mL})$, similar to verapamil (0.03-0.1 $\mu \mathrm{M})$. Since control of GI smooth muscles is largely dependent on intracellular calcium concentration and this increased intercellular calcium stimulates the GI motility that can lead to diarrhea (Trevor et al., 2010). So, a calcium channel blocker can be useful in

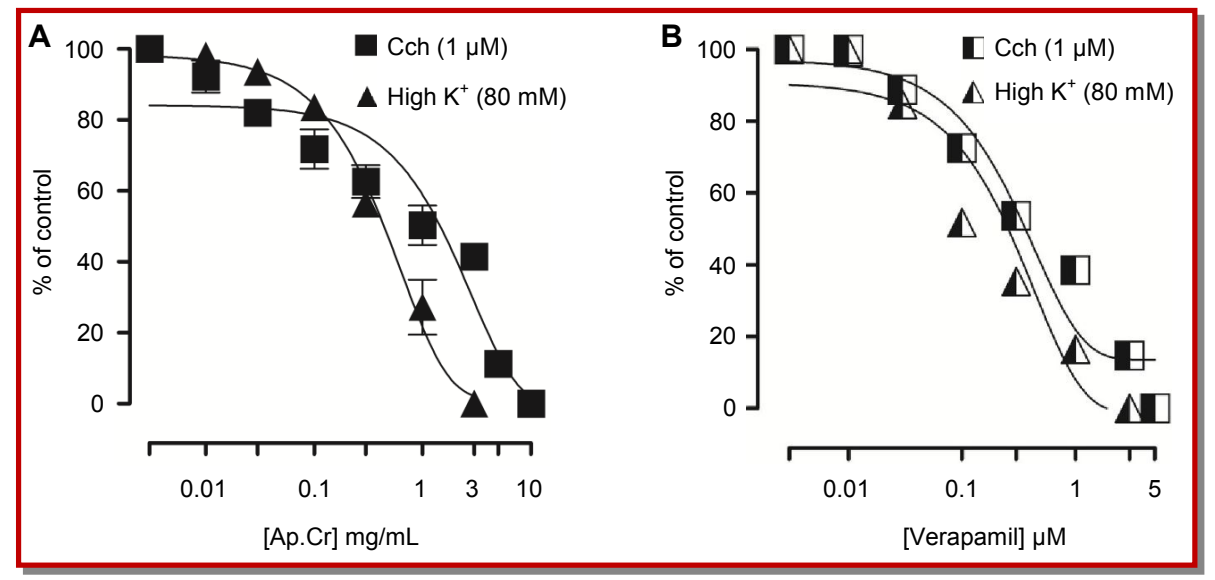

Figure 2: Concentration dependent inhibitory effect of (A) crude extract of A. pindrow (Ap.Cr) and (B) verapamil on high $\mathrm{K}^{+}(80$ $\mathrm{mM})$ and carbachol $(1 \mu \mathrm{M})$ induced pre-contracted isolated rabbit jejunum. Values are expressed as mean \pm S.E.M; $n=4$

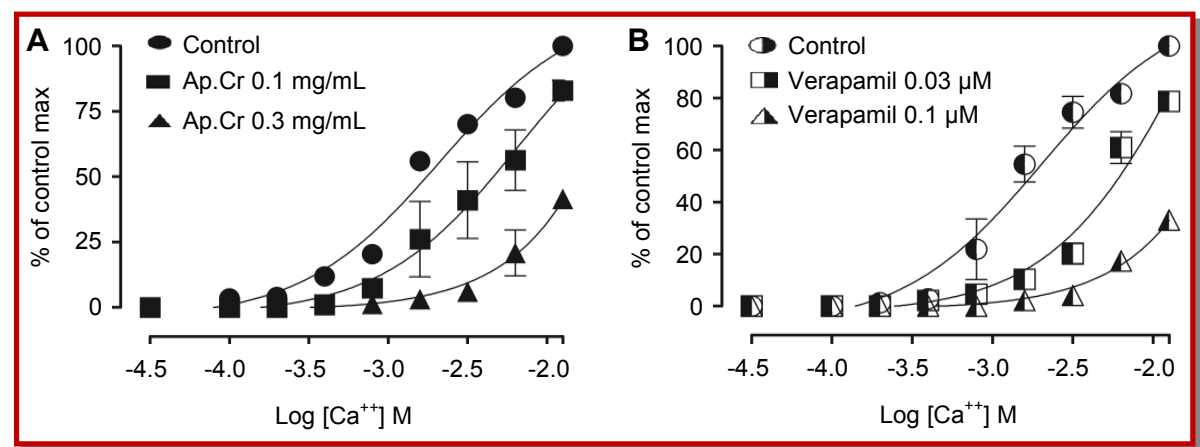

Figure 3: Concentration response curves of $\mathrm{Ca}^{2+}(\mathrm{CRCs})$ in the absence and presence of (A) crude extract of A. pindrow (Ap.Cr) and (B) verapamil on isolated rabbit jejunum. Values are expressed as mean \pm S.E.M; $n=3$ 


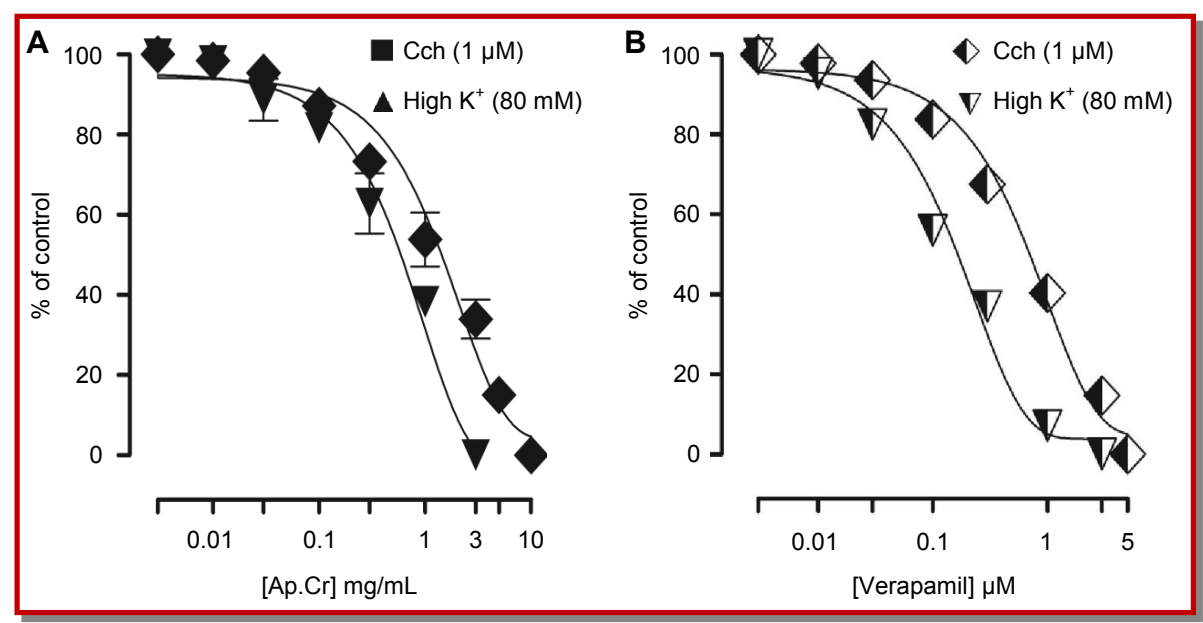

Figure 4: Concentration dependent inhibitory effects of (A) crude extract of A. pindrow (Ap.Cr) and (B) verapamil on high $\mathrm{K}^{+}(80$ $\mathrm{mM})$ and carbachol $(1 \mu \mathrm{M})$ induced pre-contracted isolated rabbit tracheal preparations. Values are expressed as mean \pm S.E.M; $\mathrm{n}=$ 3-5

hyperactive gut disorders, like diarrhea (Keith et al., 2011). The presence of calcium channel blocking activity in crude extract may give the possible explanation for traditional use of plant in diarrhea.

Based upon the folkloric repute of $A$. pindrow in respiratory ailments, the crude extract was further investigated for its possible bronchodilator effect (Chopra et al., 1956). The crude extract, concentration dependently, inhibit high $\mathrm{K}^{+}$or carbachol-induced contraction in isolated tracheal preparations similar to verapamil, revealed the presence of non-specific bronchodilator activity, possibly mediated through calcium channel blockade. Calcium channel blockers have therapeutically potential effect in respiratory disorders (Twiss et al., 2002). So, the observed calcium channel blocking activity in crude extract may give the bases for the use of $A$. pindrow as bronchodilator remedy.

Findings of current study validate the traditional uses of $A$. pindrow in GIT and respiratory disorders and strongly suggest the calcium channel blocking activity as pharmacological basis behind its anti-diarrheal and bronchodilator activity.

\section{References}

Ahmed T. Calcium antagonists: Potential for asthma therapy. Choices Respir Manage. 1992; 22: 41-43.

Asolkar LV, Kakkar KK, Charke OJ. Second supplement to glossary of Indian medicinal plants with active principles: A -K (1965-1981). New Delhi, Publications and Information Directorate, 1992

Awan MH. Kitab Ul Mufradat. Lahore, Shiekh Ghulam Ali and Sons (Pvt) Limited, 1960.

Berridge MJ, Bootman MD, Roderick HL. Calcium signaling: Dynamics, homeostasis and remodeling. Nat Rev Mol Cell

\section{Biol. 2003; 4: 517-29.}

Bolton TB. Mechanism of action of transmitters and other substances on smooth muscles. Physiol Rev. 1979; 59: 606718.

Brading AF. How do drugs initiate contraction in smooth muscles? Trends Pharmacol Sci. 1981; 2: 261-65.

Chaudhary MA, Imran I, Bashir S, Mehmood MH, Rehman NU, Gilani AH. Evaluation of gut modulatory and bronchodilator activities of Amaranthus spinosus Linn. BMC Complement Altern Med. 2012; 12: 166.

Chopra R, Nayar SL, Chopra IC. Glossary of Indian medicinal plants. New Delhi, Publications and Information Directorate, 1956.

Farre AJ, Colombo M, Fort M, Gutierrez B. Differential effects of various $\mathrm{Ca}^{2+}$ antagonists. Gen Pharmacol. 1991; 22: 17781.

Godfraind T, Miller R, Wibo M. Calcium antagonism and calcium entry blockade. Pharmacol Rev. 1986; 38: 321-416

ILAR (Institute of Laboratory Animal Resources, US). Guide for the care and use of laboratory animals. Washington DC, National Academies Press, 1996.

Keith A, Sharkey, John LW. Treatment of bowel motility and water flux; anti-emetic; agents used in biliary and pancreatic disease. In Goodman and Gilman's The pharmacological basis of therapeutics. Brunton LL, Chabner BA, Knollmann BC (ed). China, McGraw-Hill Medical, 2011, pp 1323-50.

Khare CP. Indian medicinal plants: An illustrated dictionary. New Delhi, Springer, 2007.

Kumar V, Singh RK, Jaiswal AK, Bhattacharya SK, Acharya SB. Anxiolytic activity of Indian Abies pindrow Royle leaves in rodents: An experimental study. Indian J Expbiol. 2000; 38: 343-46.

Majeed H, Bokhari TZ, Sherwani SK, Younis U, Shah MHR, Khaliq B. An overview of biological, phytochemical and pharmacological value of Abies pindrow. J Pharmacogn Phytochem. 2013; 2: 182. 
Michael T, Hoffman BB. Treatment of myocardial ischemia and hypertension. In: Goodman and Gilman's The pharmacological basis of therapeutics. Brunton LL, Chabner BA, Knollmann BC (ed). China, McGraw-Hill Medical, 2011, pp 745-88.

Nadal FJA, Atucha NM, Iyu D, García-Estañ J. Interaction of nitric oxide with calcium in the mesenteric bed of bile ductligated rats. Bri J Pharmacol. 2002; 135: 489-95.

Nadkarni KM. Indian material medica: With Ayurvedic, Unani -Tibbi, Siddha, Allopathic, Homeopathic, Naturopathic \& Home Remedies, Appendices \& Indexes. Popular Prakashan, 1996.

Qureshi HM, Omer MO, Ashraf M, Bukhsh A, Chaudhry MA, Imarn MS. Evaluation of antihistaminic and anticholinergic activities of Murraya koenigii Linn. Pak Vet J. 2015.

Radha B, Dinesh S, Tiwari JK, Tiwari P. Diversity and availa- bility status of ethno-medicinal plants in the lohba range of kedarnath forest division (KFD), Garhwal Himalaya. Glob J Res Med Plants Indigen Med. 2013; 2: 198-212.

Trevor AJ, Katzung BG, Masters SB (ed). Katzung \& Trevor's pharmacology: Examination \& board review. Singapore, McGraw-Hill Medical, 2010, pp 59-60.

Twiss MA, Harman E, Chesrown S, Hendeles L. Efficacy of calcium channel blockers as maintenance therapy for asthma. Bri J Clin Pharmacol. 2002; 53: 243-49.

urRahaman MS, Chaudhary MA, Ahmad B, Alamgeer A. Rationalization of traditional uses of Berberis lycium in gastrointestinal disorders. Br J Med Med Res. 2013; 3: 868-79.

Yasin M, Janbaz KH, Imran I, Gilani AH, Bashir S. Pharmacological studies on the antispasmodic, bronchodilator and anti-platelet activities of Abies webbiana. Phytother Res. 2014; 28: $1182-87$

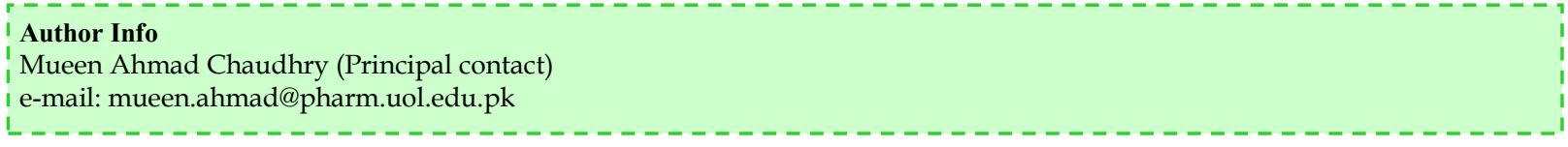

